\title{
The birth of global knowledge: intellectual networks in the world crisis, 1919-1939
}

\author{
Stephen Wertheim ${ }^{1} \cdot$ Ludovic Tournès $^{2}$. \\ Inderjeet Parmar ${ }^{3}$
}

\section{Introduction}

This special double issue of International Politics examines the production of global knowledge in the interwar period. In anticipation of the centenary of the Royal Institute of International Affairs in London (1920) and the founding of the Council of Foreign Relations in New York (1921), it explores how think tanks and similar organisations generated and still generate knowledge of the world and by so doing helped and help constitute what is now called 'global governance'.

\footnotetext{
1 The Commission on Global Governance (1995).
}

This special issue derives in part from a workshop titled '(re)Thinking the Global Crisis, 1919-1939', held at the University of Geneva in October 2015 and organised by Jeremy Adelman and Ludovic Tournès. The editors would like to thank Michael Cox for encouraging the publication of this special issue and all the reviewers for helping us to improve the articles and shape the volume.

Ludovic Tournès

Ludovic.Tournes@unige.ch

Stephen Wertheim

stephen.wertheim@columbia.edu

Inderjeet Parmar

Inderjeet.parmar.1@city.ac.uk

1 Department of History, Columbia University, 1180 Amsterdam Avenue, New York, NY 10027, USA

2 Department of History, Global Studies Institute, University of Geneva, rue Saint-Ours 5, 1211 Geneva 4, Switzerland

3 Department of International Politics, City, University of London, Northampton Square, London EC1V OHB, UK 
These institutions have their origin in the interwar period-years normally defined negatively, as little more than a way station between the First and Second World Wars. Indeed, scholars often associate globalisation with the surrounding periods, and global governance with the contemporary era after 1945 or even $1991 .^{2}$ But these assumptions, implied by the transitional designation 'interwar period' itself, have prevented scholars from attending to the global phenomena that arose and developed in these years.

We consider the 1920s and the 1930s as fertile decades in the long-range history of global governance and global knowledge. Not only did the victorious powers of World War I attempt to construct a new world order, aiming to bring about the 'organisation' - to use a master signifier of the times - of international life. Their liberal, Eurocentric order also inspired all manner of challenges, especially from colonial subject peoples and communist and fascist movements. These clashing projects of order building shaped world politics for decades to come, regardless of whether they succeeded or failed on their own terms. A major dimension of building new world orders, and contesting rival alternatives, was the construction of knowledge on global problems-not only political and economic but also social, intellectual, and cultural in nature.

From the vantage point of the twenty-first century, the interwar world emerges as the birthplace of familiar forms of global knowledge. Soon after the first crop of think tanks was established in and just after World War I, they became normative fixtures of national and international governance, parts of the landscape of global politics. Yet the development of global knowledge was not linear. Just as 'think tank' is a retrospective moniker, the archetype of the think tank ill describes many of the first knowledge organisations. True, some like the Council on Foreign Relations were largely nationally oriented institutions aiming to use expert knowledge to inform the decision-making of policymakers at the highest levels of a single state. But others differed radically from such a model, which the Council itself imperfectly fits, being initially conceived as a branch of an Anglo-American organisation. ${ }^{3}$

In order to historicise the birth of global knowledge, the authors of this special issue emphasise three areas of inquiry that capture particularities of global politics in the interwar period. One concerns novel efforts to organise knowledge of the world through official, semi-official, and unofficial institutions and networks. A second area is the relationship between global knowledge and the emerging social sciences. Although the social sciences ultimately came to be anchored in the university, pioneering work was also performed in non-academic or semi-academic venues during interwar period, especially when it came to economics or the nascent interdisciplinary field of International Relations. Third, we consider the international sites of international knowledge-how global knowledge was produced in space and produced new conceptions of space.

\footnotetext{
2 Notable exceptions include, among others, Mazower (2012).

3 See Parmar (2004).
} 


\section{The international organisation of knowledge}

First and foremost, this issue exhumes the lattice-work of institutions that sprung up in the decades surrounding World War I. Scholarship on such institutions has concentrated on a handful of examples: the Carnegie Endowment for International Peace (created in 1910), the Brookings Institution (1916), the Royal Institute of International Affairs (or Chatham House, 1920), and the Council on Foreign Relations (1921). But international knowledge organisations were not merely an Anglo-American phenomenon, and they were many in number. The interwar years witnessed the creation of dozens of institutions dedicated to producing knowledge and considering the world as a whole unit of analysis.

Knowledge organisations assumed diverse forms. Priscilla Roberts examines the Institute of Pacific Relations, whose confederal structure, with branches in 15 nations across four continents, made it an international non-governmental organisation in its own right. Until World War II, the Institute prohibited government officials from participating in its meetings. On the other hand, the Council on Foreign Relations undertook secret post-war planning on behalf of the US State Department in 1940 and 1941, even if, as Luke Fletcher finds, its expertise may not have been heeded. Other organisations were intergovernmental, such as the Institut Colonial International, studied by Cyrus Schayegh, or the technical sections of the League of Nations, analysed by Ludovic Tournès. Interwar knowledge organisations ran the gamut between public and private, formal and informal, short lived and long lasting.

Today the ideal-typical think tank aims to deliver research to official policymakers, and some interwar knowledge organisations fit this pattern. But many sought to reach different audiences. After the Paris Peace Conference enthroned 'international public opinion' as a discursive frame for claim-making, enterprising intellectuals and activists set out to build common understanding at popular and unofficial elite levels as much as they sought to impact national policymakers. ${ }^{4}$ This was certainly true, for example, of the Pan-African Conferences examined by Mark Ledwidge and Inderjeet Parmar. The new media of radio and film played an important role in this regard, yet print media remained important. Roberts stresses that the Institute of Pacific Relations published pamphlets targeting a wide public. Similarly, the Carnegie Endowment for International Peace funded the creation of dozens of International Mind Alcoves in US public libraries, offering books and pamphlets on international problems for a non-academic public. ${ }^{5}$

The crises of the 1930s had paradoxical effects on knowledge as an aspect of world organisation. On the one hand, great-power conflict and ideological competition threw the efficacy of political organisation in doubt and elevated the importance of 'non-political' bodies. On the other hand, new and existing knowledge institutes increasingly produced knowledge for the consumption of national governments, as illustrated by Fletcher's study of the USA and Benjamin Martin's of Nazi Germany. Less confident that the spread of knowledge could

\footnotetext{
${ }^{4}$ On the concept of international public opinion, see Donaldson (2016) and Wertheim (2018).

5 See Witt (2014).
} 
progressively transcend power politics, they undertook to harness knowledge in the struggle among liberal, communist, and fascist alternatives.

\section{Global knowledge and the social sciences}

The emergence of global knowledge is inseparable from the development of science, especially social science, and this theme constitutes the second focus of this issue. Forged in the name of international organisation and public opinion, the peace of 1919 was also proclaimed to be a 'scientific peace'. In the succeeding decades, researchers forged the modern social sciences, conceived as disciplines marked off by coherent aims and methods, and conducted by professional specialists. ${ }^{6}$ How far, then, did global knowledge spur the development of the social sciences? Or did the growth of non-academic knowledge organisations-often insisting upon methodological pluralism - inhibit the formation of academic disciplines? Under what circumstances have knowledge institutes influenced academic research and political practice, and when have they instead guarded existing intellectual frameworks against innovative challenges?

In particular, this special issue provides several cases of how non-governmental, non-academic institutes nurtured interwar International Relations, which constituted a field but not yet an academic discipline, since it advanced no claim to methodological specificity. As is well known, the first chair in International Relations was created at the University of Aberystwyth in 1919 funded by the industrialist David Davies; in the 1920s, the even wealthier Ernest Cassel bankrolled the first IR chair at the London School of Economics; meanwhile, Carnegie money helped set up and support various 'endowments' for International Peace in Europe and the USA. And at a time when many universities were only just becoming centres of research, institutes outside the university were crucial in performing, coordinating, and funding studies of world affairs. How did this institutional setting of IR shape the field's ideas and sensibilities? James Cotton offers compelling answers in his study of the Chatham House project. Although the founders of the IR field sought to establish the scientific, systematic study of international problems, they aimed both to guide policymakers and to tutor public opinion. As a consequence, books written by IR specialists of the Chatham House galaxy emphasised general ideas above methodological problems, a pattern that opened up such specialists to the charge of 'idealism' after World War II.

Another growing field in the interwar years was the comparative study of races and civilisations. Building on the recent work of Robert Vitalis, Ledwidge and Parmar underscore the importance of the racial-imperial mindset of US funders of IR, who conceived the new field as an 'instrument to comprehend and manage global race relations'. ${ }^{7}$ Craig Brandist, too, demonstrates that a phenomenon resembling Western 'area studies' existed in the Soviet Union as early as the 1920s, when Soviet intellectuals engaged in complex discussions under the rubric of

\footnotetext{
6 See Heilbron et al. (2008).

7 See Vitalis (2015).
} 
'oriental studies'. In addition, a set of disciplines mushroomed in the context of colonial empire: ethnology, anthropology, colonial sociology, colonial law, and so on. Schayegh illustrates the use of these disciplines in the Institut Colonial International; other sites included the Institut d'ethnologie created in France in 1927. Colonial sciences fostered knowledge about the globe but also, of course, sought to manage and reform empires in order to strengthen them.

Not all forms of expert knowledge of world affairs pointed the way towards the post-1945 social sciences. One active field was statistics, considered in the interwar period to be a social science in its own right. The technical bodies of the League of Nations, especially the Epidemiologic Intelligence Service and the Economic Intelligence Service, used statistics to create knowledge of the world, as Ludovic Tournès shows. In addition, throughout the first half of the twentieth century, international law provided a lingua franca for experts and diplomats alike, as the divergent cases of liberal Latin American legalists, in Theresa Davis's article, and Nazi-fascist jurists, in Martin's account, attest. As Fletcher reveals, however, experts in the increasingly formalised social sciences, like the economists Hansen Baldwin and Jacob Viner, were at the vanguard in the Council on Foreign Relations by the early years of World War II.

\section{Knowledge in and of space}

Finally, this issue moves beyond Eurocentric narratives of the interwar period in order to apprehend the connections and rivalries that played out on a truly global scale. ${ }^{8}$ We offer case studies of the global yet differential circulation of knowledge and the global yet particularistic imaginaries of space that proliferated in the interwar years. Categories as familiar as the Commonwealth, the Pacific, and the South date to this period. Rather than narrate a monolithic liberal internationalism and isolate its trajectory in history, we emphasise the perhaps uniquely fluid ways in which world order was imagined and contested in the wake of World War I. This sense of possibility emerged straight from the cataclysms of the war-the Bolshevik revolution against capitalism, imperialism, and national chauvinism; the dissolution of the Austro-Hungarian empire and the humiliating defeat of Germany; the rejuvenation of colonial empire, against rising national, regional, and global anticolonialisms; and the erection of the League of Nations and related institutions in Geneva. How, we ask, did participants in global knowledge networks comprehend and construct national, regional, imperial, civilisational, and global spatialities?

Several articles probe attempts to maintain and even invigorate empire, generating new globe-spanning spatialities. Ledwidge and Parmar argue that British imperial and racial views evolved after 1919 into a more liberal and progressive conception of world order, resulting in the transformation of the idea of Empire to that of the Commonwealth. Cotton demonstrates how the Commonwealth idea spread in the global South through the activities of the Royal Institute of International Affairs and its sister institutions in the Dominions. Schayegh,

\footnotetext{
${ }^{8}$ See, for example, Conrad and Sachsenmaier (2007) and Gerwarth and Manela (2014).
} 
conversely, focuses on the way Belgium, a small country and a minor power, tried to legitimate its administration of the extensive territory of the Congo by promoting the notion of Eurafrica and appealing to the ideal of cooperation among imperial powers. Belgium's effort, Schayegh shows, was supported by the Institut Colonial International, whose scientific work was inseparable from propaganda dedicated to justifying colonial rule.

Sometimes overlooked by global historians were regionalist projects that bourgeoned in the interwar years and were embedded, to varying degrees, within universalistic conceptions. For Davis, South American jurists turned to regionalisation after being rebuffed in the World War I peacemaking; before the war, Davis reveals, they promoted forms of Pan-American cooperation that sought to integrate the region into the global liberal economic order whilst tempering US and European political-military interventionism. Brandist demonstrates how interwar Soviet intellectuals constructed the (mostly Muslim) East as a discrete area for Bolshevik foreign policy. Roberts indicates that the Institute of Pacific Relations helped to produce its object of inquiry, the Pacific, whilst promoting a 'pan-Pacific model of a collaborative Western-Asian regional system'. As Xu Guoqi demonstrates, Chinese intellectuals and leaders of the May Fourth movement elaborated a conception of pan-Asianism based on the idea of self-determination and the desire to escape Japanese domination. The most regionally circumscribed project came from Nazi Germany, where, as Martin writes, jurists struggled to win the regime's assent even to rally likeminded Europeans around German continental hegemony.

Certain actors, however, came to see the world as a unified, interconnected entity. Small wonder that the League proved conducive to such views, as Tournès argues. From their perch in Geneva, experts in the League's technical sections took global perspectives and elaborated international norms on their fields of competence. They enjoyed the financial support of the globally minded Rockefeller Foundation. Another global view in the USA held sway by 1941: Fletcher documents how postwar planners in the Council on Foreign Relations defined US interests in global terms, breaching the hemispheric constraints of the traditional Monroe Doctrine.

\section{Rethinking the 'interwar period'}

In sum, this issue contributes a missing dimension-the organisation of global knowledge-to historians' and political scientists' ongoing revaluation of interwar experiments in international politics. The 1920s and 1930s were decades of innovation and renewal, more continuous with the post-1945 years than we frequently imagine. At the same time, as historians revisit the interwar crisis, they should find significance in the foreign as well as the familiar. Doing so serves not only the anthropological function of making present structures seem strange and opening up alternative imaginaries. It also gives meaning to the interwar period as a period, not just a prelude. Between the wars, internationalist projects dating to the nineteenth century reached their apotheosis. Susan Pedersen's landmark The Guardians, for example, traces how the Mandates System implemented the Victorian ideal that 'the international' could stand above the interests of colonial 
empires. Contested by native peoples, imperial lobbies, and fascist and communist powers, this ideal collapsed, reducing the international to 'little more than the arena in which [states'] battles would be fought out' ${ }^{9}$ In failure, too, the past mattered: a realist sensibility would ground the next world order, forever marked by the collapse of the last.

\section{References}

Conrad, S., and D. Sachsenmaier (eds.). 2007. Competing Visions of World Order: Global Moments and Movements, 1880s-1930s. New York: Palgrave MacMillan.

Donaldson, M. 2016. 'From Secret Diplomacy to Diplomatic Secrecy: Secrecy and Publicity in the International Legal Order: 1919-1950', J.S.D. dissertation, New York University School of Law.

Gerwarth, R., and E. Manela (eds.). 2014. Empires at war 1911-1923. Oxford: Oxford University Press.

Heilbron, J., N. Guilhot, and L. Jeanpierre. 2008. Toward a Transnational History of the Social Sciences. Journal of the History of the Behavioral Sciences 44(2): 146-160.

Mazower, M. 2012. Governing the World: The History of an Idea. New York: Penguin.

Parmar, I. 2004. Think Tanks and Power in Foreign Policy: A Comparative Study of the Role and Influence of the Council on Foreign Relations and the Royal Institute of International Affairs, 1939-1945. Basingstoke: Palgrave.

Pedersen, S. 2015. The Guardians: The League of Nations and the Crisis of Empire. New York: Oxford University Press.

The Commission on Global Governance. 1995. Our Global Neighbourhood. Oxford: Oxford University Press.

Vitalis, R. 2015. White World Order, Black Power Politics: The Birth of American International Relations. Ithaca: Cornell University Press.

Wertheim, S. 2018. 'Reading the International Mind: International Public Opinion in Early Twentieth Century Anglo-American Thought' in D. Bessner and N. Guilhot (eds.) The Decisionist Imagination: Democracy, Sovereignty and Social Science in the 20th century. New York: Berghahn Books.

Witt, S. 2014. International Mind Alcoves: The Carnegie Endowment for International Peace, Libraries, and the Struggle for Global Public Opinion, 1917-54. Library \& Information History 30(4): 273-290.

\footnotetext{
9 See Pedersen (2015), 401.
} 